\title{
A EuRopean SAVIng Test FOR SECTION 92 OF THE Australian CONSTITUTION
}

\author{
Gonzalo Villalta Puig
}

This article celebrates the recent decision of the High Court of Australia in Betfair Pty Ltd v Western Australia to revise the uniquely Australian concept of abridged proportionality that frames the Cole v Whitfield saving test for section 92 of the Australian Constitution. The critique that the article makes of abridged proportionality takes the form of a comparison with the continental European concept of robust proportionality. The comparison reveals that, unlike robust proportionality, abridged proportionality poses a twofold risk: one, that the test might save laws or measures that have a discriminatory effect on interstate trade and commerce if they have a purpose that is not protectionist; and, two, that the test might not save laws or measures that, in effect, legitimately regulate interstate trade and commerce if they have a purpose that is indeed protectionist. Thus, the article argues that abridged proportionality cannot preserve the Australian common market with the same level of strength that robust proportionality has. In conclusion, the article celebrates the fact that, since Betfair Pty Ltd v Western Australia, the High Court of Australia is now free to analyse not only the purpose but also the effect of any law or measure under challenge when it considers future cases on section 92.

\section{INTRODUCTION}

Section 92 of the Australian Constitution guarantees the free movement of goods among the States and Territories of the Commonwealth. The text of the section reads: 'trade, commerce, and intercourse ... among the States ... shall be absolutely free'.

With the exception of the phrase 'absolutely free', the High Court of Australia has given the words of the section a clear and certain meaning.

* BA LLB(Hons) GradDipLegPrac(Merit) ANU LLM Canberra GradCertHigherEd LLM(GBL) SJD La Trobe LLD Navarra, Barrister and Solicitor of the High Courts of Australia and New Zealand and Solicitor of the Supreme Court of England and Wales. 
However, the Court has had difficulty in interpreting the meaning of the phrase 'absolutely free'. The difficulty with the phrase is that it is logically incomplete. The section does not state what it is from which interstate trade and commerce is to be absolutely free. Accordingly, the Court has not been able to read the phrase without any qualification.

The interpretation of section 92 rapidly became a judicial labyrinth and remained chaotic until 1988 when the Court in Cole v Whitfield ${ }^{1}$ resolved to develop a definitive test for section 92. The Court developed a twofold test for section 92 .

The first test is discriminatory protectionism. It is an invalidity test. The test declares a law or measure invalid if it imposes a burden on interstate trade and commerce that is discriminatory in a protectionist sense. The second test is abridged proportionality. It is a saving test. The test declares a law or measure valid if it has a purpose that is not protectionist and any burden that it imposes on interstate trade and commerce is appropriate and adapted to the achievement of that purpose.

Since 1988, academic commentators have considered the Cole $v$ Whitfield twofold test as the definitive test for section 92. The Court, too, has considered the test as definitive and, two years later, confirmed the test in Castlemaine Tooheys Ltd v South Australia. ${ }^{2}$ The Court has not revised the law on section 92 since then. However, I do not consider that the Cole v Whitfield test for section 92 is definitive. Indeed, this article is a doctrinal critique of the Cole $v$ Whitfield saving test for section 92.

I argue that the Court should revise the uniquely Australian concept of abridged proportionality that frames the Cole $v$ Whitfield saving test for section 92. Discriminatory protectionism tests the invalidity of a law or measure under challenge for an alleged contravention of section 92 . The test declares a law or measure invalid if it imposes a burden on interstate trade and commerce that is discriminatory in a protectionist sense. However, the Court retains the discretion to save that law or measure even if, in principle, it contravenes the section. Just as there is an invalidity test for section 92 , there is also a saving test.

My critique of abridged proportionality takes the form of a comparison with the continental European concept of robust proportionality. The comparison

\footnotetext{
${ }^{1}$ (1988) 165 CLR 360.

2 (1990) 169 CLR 436.
} 
reveals that the test of abridged proportionality requires the Court to assess the suitability of the law or measure under challenge. In order to undertake that assessment, the Court needs only to analyse the purpose of the law or measure. In comparison, the test of robust proportionality requires the Court to assess not only the suitability but also the necessity of the law or measure and the balance between the freedom in section 92 and the restriction of that freedom by the law or measure. In order to undertake that assessment, the Court needs to analyse both the purpose and the effect of the law or measure under challenge. By implication, therefore, the test of abridged proportionality risks saving laws or measures that have a discriminatory effect against interstate trade and commerce if they have a purpose that is not protectionist. Accordingly, I argue that abridged proportionality cannot preserve the common market with the same level of strength that robust proportionality has. Furthermore, I argue that the emphasis of the test of abridged proportionality on the purpose of the law or measure under challenge is problematic because it implies a looser and instrumental use of facts.

In conclusion, I argue that, instead of the concept of abridged proportionality as the Cole $v$ Whitfield saving test for section 92, the Court should assess not only the suitability but also the necessity and balance of the law or measure under challenge. With a more robust concept of proportionality, the Court would analyse not only the purpose but also the effect of the law or measure.

Thus, I argue for robust proportionality and criticise the reluctance of the Court to introduce the concept even though there is judicial precedent and academic commentary in support of its introduction.

\section{The Cole $v$ Whitfield SAVing Test for Section 92 OF THE AUSTRALIAN CONSTITUTION}

\section{A Introduction}

I argue that the saving test developed by the High Court of Australia in Cole $v$ Whitfield and Castlemaine Tooheys Ltd v South Australia as a complement to discriminatory protectionism is doctrinally flawed. I base my argument on a claim that relates to the concept of abridged proportionality as a saving test for section 92 of the Australian Constitution.

I claim that abridged proportionality fails to meet the federal purpose of a common market that the founders intended for section 92. The reason is twofold. One reason is that the test is based on an inadequate understanding 
of proportionality. Another reason, which flows directly from the first, is that the test is concerned with the purpose and not with the effect of the law or measure under challenge. This approach implies that the Court can allow laws or measures that, nominally, have a constitutionally valid purpose even though, in effect, they violate the common market.

\section{B The Rationale for a Saving Test for Section 92 of the Australian Constitution}

The rationale for a saving test is obvious, even when it concerns, as in the case of section 92, the guarantee of a freedom. The rationale is the need for genuine regulation of interstate trade and commerce. Hinting at proportionality as the conceptual framework for a saving test for section 92, Patrick Smith explained in The Australian Law Journal the rationale for the genuine regulation of interstate trade and commerce notwithstanding that section 92 guarantees the free movement of goods:

In ... Australia $\ldots$ there is the understanding that national or State regulation must be permissible in certain circumstances even where such regulation hinders the free movement of goods. In examining the extent of permissible regulation we have seen that the common factor is the application of the concept of proportionality in [the] court's saving test ... ${ }^{3}$

Accordingly, the Court in Cole $v$ Whitfield felt obliged to acknowledge that the guarantee against protectionism is not absolute. Indeed, it recognised that, at times, there is a need for genuine regulation of intrastate and interstate trade and commerce. In this regard, the Court stated:

A law which has as its real object the prescription of a standard for a product or a service or a norm of commercial conduct will not ordinarily be grounded in protectionism and will not be prohibited by s. 92. But if a law, which may be otherwise justified by reference to an object which is not protectionist, discriminates against inter-State trade or commerce in pursuit of that object in a way or to an extent which warrants characterisation of the law as protectionist, a court will be justified in concluding that it nonetheless offends s. $92{ }^{4}$

\footnotetext{
${ }^{3}$ Patrick J Smith, 'Free Movement of Goods within the EC and s 92 of the Australian Constitution' (1998) 72 Australian Law Journal 465, 477 (emphasis added).

${ }^{4}$ Cole $v$ Whitfield (1988) 165 CLR 360, 408 (emphasis added).
} 


\section{The Origins of the Cole v Whitfield Saving Test}

The saving test for section 92 was sketched in Cole $v$ Whitfield but it was only fully canvassed in Castlemaine Tooheys Ltd $v$ South Australia:

Both Cole $v$ Whitfield and Castlemaine Tooheys indicate that reasonable regulation is compatible with $s 92$, provided that the burden imposed on interstate trade is incidental and not disproportionate to the legitimate object to be achieved. ${ }^{5}$

The saving test revolves around the concept of proportionality. The Court began to toy with the concept many years before Cole $v$ Whitfield. Incidentally, one of its leading exponents on the Bench was Mason J. For example, in the 1980 case of Uebergang $v$ Australian Wheat Board, ${ }^{6}$ Mason J, together with Stephen J, imagined a saving test that would reconcile otherwise infringing legislation with section 92 provided that the legislation be 'no more restrictive than is reasonable in all the circumstances, due regard being had to the public interest'. 'Their Honours explained their concept of proportionality further:

The evidence which we would regard as relevant in determining the validity of the present legislation would be such material as would enable the court to determine whether or not the restrictions which the legislation imposes upon interstate trade are no greater than are reasonably necessary in all the circumstances. ${ }^{8}$

In 1983, three years after this influential judgment, Deane $\mathrm{J}$ formally introduced proportionality, as a distinct concept, into federal constitutional law. ${ }^{9}$ In Commonwealth $v$ Tasmania, ${ }^{10}$ his Honour declared that, in order to be valid, a law or measure must be capable of being reasonably considered to be appropriate and adapted to achieving what is said to provide it with the character of a law or measure with respect to the particular subject matter. In

\footnotetext{
${ }^{5}$ Gabriel Moens and John Trone, Lumb \& Moens' The Constitution of the Commonwealth of Australia Annotated (6 ${ }^{\text {th }}$ ed, 2001) 314,325 (emphasis added).

${ }^{6}$ (1980) 145 CLR 266.

7 Uebergang $v$ Australian Wheat Board (1980) 145 CLR 266, 306 (Stephen and Mason JJ) (emphasis added).

${ }_{9}^{8}$ Ibid (emphasis added).

9 Jeremy Kirk, 'Constitutional Guarantees, Characterisation and the Concept of Proportionality' (1997) 21 Melbourne University Law Review 1, 2.

${ }^{10}$ (1983) 158 CLR 1 ('Tasmanian Dam Case').
} 
other words, reasonable proportionality is necessary between the designated purpose and the means that the law or measure embodies for achieving it: ${ }^{11}$

Implicit in the requirement that a law be capable of being reasonably considered to be appropriate and adapted to achieving what is said to provide it with the character of a law with respect to external affairs is a need for there to be a reasonable proportionality between the designated purpose or object and the means which the law embodies for achieving or procuring it. Thus, to take an extravagant example, a law requiring that all sheep in Australia be slaughtered would not be sustainable as a law with respect to external affairs merely because Australia was a party to some international convention which required the taking of steps to safeguard against the spread of some obscure sheep disease which had been detected in sheep in a foreign country and which had not reached these shores. ${ }^{12}$

Since 1983, 'the proportionality doctrine has taken root and, indeed, extended its reach into the heartland of federal constitutional law'. ${ }^{13}$ These words, which Gummow J wrote in Minister for Resources $v$ Dover Fisheries Pty $L t d,{ }^{14}$ reflect on the state of the law after Cole $v$ Whitfield and Castlemaine Tooheys Ltd v South Australia:

[I]n Australia the proportionality doctrine has taken root and, indeed, extended its reach into the heartland of federal constitutional law. First, the rather special and 'purposive' nature of the legislative power with respect to external affairs in its application to existing and reasonably apprehended international obligations, led to its confinement to what may reasonably be regarded as appropriate means for implementation of the obligation: Commonwealth v Tasmania (the Tasmanian Dam case) (1983) 158 CLR 1 at 172, 232-233, 259-261; Richardson v Forestry Commission (1988) 164 CLR 261 at 295-296, 303, 311-312, 326, 336. Secondly, the doctrine has been applied to the operation of constitutional prohibitions or restraints upon the scope of legislative power, whether these prohibitions or restraints arise expressly, as with s 92 of the Constitution, (Castlemaine Tooheys Ltd v South Australia (1990) 169 CLR 436 at 473-474) or impliedly (Nationwide News Pty Ltd v Wills (1992) 177 CLR 1 at 50, 76-77, 94-95). Thirdly, the doctrine has been applied generally as a criterion of validity of provisions which fall outside the 'core' of the subject matters of certain of those legislative powers in s 51 which are not 'purposive' powers; see, as to the

\footnotetext{
${ }^{11}$ Tasmanian Dam Case (1983) 158 CLR 1, 5-6 (Deane J).

12 Ibid 260 (Deane J) (emphasis added). The quotation refers only to s 51(xxix) but the principle can extend to all laws, on all subjects.

${ }^{13}$ Minister for Resources $v$ Dover Fisheries Pty Ltd (1993) 43 FCR 565, 576 (Gummow J) (emphasis added).

${ }^{14}$ (1993) 43 FCR 565.
} 
trade marks and corporations powers, Davis v Commonwealth (1988) 166 CLR 79 at 99-100, and as to the conciliation and arbitration power, Nationwide News Pty Ltd $v$ Wills (supra) at 28-31 per Mason CJ, Dawson J contra at $88-89 .{ }^{15}$

\section{The Development of the Cole v Whitfield Saving Test}

Indeed, of particular significance to the development of the saving test for section 92 is the decision in Castlemaine Tooheys Ltd v South Australia. ${ }^{16}$ The case is important because it allowed the Court to develop the saving test that originated in Cole $v$ Whitfield, thus completing its revolutionary revision of the law on section 92. ${ }^{17}$ Castlemaine Tooheys Ltd $v$ South Australia stands as authority for the principle that a law or measure that would otherwise be held to contravene section 92 may be held valid if it aims to achieve a nonprotectionist purpose and any burden that it imposes on interstate trade and commerce is appropriate and adapted to the achievement of that purpose. ${ }^{18}$

It is important to refer to the words of the majority judgment in order to understand the concept of abridged proportionality that the Court developed in response to the Cole $v$ Whitfield test of invalidity:

In determining what is relevantly discriminatory in the context of s. 92, we must take account of the fundamental consideration that, subject to the Constitution, the legislature of a State has power to enact legislation for the well-being of the people of that State. In that context, the freedom from discriminatory burdens of a protectionist kind postulated by s. 92 does not deny to the legislature of a State power to enact legislation for the wellbeing of the people of that State unless the legislation is relevantly discriminatory. Accordingly, interstate trade, as well as intrastate trade, must submit to such regulation as may be necessary or appropriate and adapted either to the protection of the community from a real danger or threat to its welfare or to the enhancement of its welfare. ${ }^{19}$

Conversely:

\footnotetext{
${ }^{15}$ Ibid.

${ }^{16}$ Castlemaine Tooheys Ltd v South Australia (1990) 169 CLR 436.

${ }^{17}$ Gerard Carney, 'The Re-Interpretation of Section 92: The Decline of Free Enterprise and the Rise of Free Trade' (1991) 3 Bond Law Review 149, 159.

${ }^{18}$ Moens and Trone, above n 5, 324.

${ }^{19}$ Castlemaine Tooheys Ltd $v$ South Australia (1990) 169 CLR 436, 472 (Mason CJ, Brennan, Deane, Dawson, and Toohey JJ).
} 
The fact that a law imposes a burden upon interstate trade and commerce that is not incidental or that is disproportionate to the attainment of the legitimate object of the law may show that the true purpose of the law is not to attain that object but to impose the impermissible burden. ${ }^{20}$

\section{E Conclusion}

In summary, according to Castlemaine Tooheys Ltd v South Australia, section 92 is not infringed where the 'legislative measures ... are appropriate and adapted to the resolution of those problems [and] any burden imposed on interstate trade was incidental and not disproportionate to their achievement'. ${ }^{21}$ Some years ago, Christopher Staker synthesised the saving test in formulaic, almost mathematical, terms in the Federal Law Review:

[Section] 92 does require that State laws and measures which do impose burdens on interstate trade should never be adopted without purpose, and that the burdens they impose should not exceed that which is reasonably necessary to achieve that purpose. ${ }^{22}$

\section{ABRIDged PROPORTIONALITY AND ROBUSt PROPORTIONALITY}

The passage from Staker above summarises with accuracy and simplicity the saving test that the High Court of Australia developed in Castlemaine Tooheys Ltd $v$ South Australia as an antidote to a finding of discriminatory protectionism under the Cole $v$ Whitfield test of invalidity. The saving test arose out of the need for the genuine regulation of interstate trade and commerce and was faithful to the original views of Mason $\mathrm{J}$ as proclaimed in Uebergang $v$ Australian Wheat Board.

However, notwithstanding its unarguable rationale and consistency with precedent, the saving test is doctrinally flawed. The passage from Staker above readily identifies the flaws. They are two in number. They relate to the concept of abridged proportionality that underpins the test and the subsequent concern that the test has with legislative purpose over and beyond legislative effect.

\footnotetext{
${ }^{20}$ Ibid (emphasis added).

${ }^{21}$ Ibid (emphasis added).

22 Christopher Staker, 'Section 92 of the Constitution and the European Court of Justice' (1990) 19 Federal Law Review 322, 343. See also Christopher Staker, 'Free Movement of Goods in the EEC and Australia: A Comparative Study' (1990) 10 Yearbook of European Law 209.
} 
The first flaw is that the saving test revolves around a concept of proportionality that, whilst tailored to fit around section 92 of the Australian Constitution, does not reflect the vision that the founders had for the section. The saving test is based on a very superficial concept of proportionality. This particular concept has been labelled as 'abridged proportionality'. This understanding is nothing other than an abridgement of robust proportionality.

\section{A Robust Proportionality}

To understand the distinction between abridged proportionality and robust proportionality, it is necessary to understand the theoretical considerations that lie behind the concept of proportionality itself. Proportionality is not a concept unique to Australian constitutional law. Rather, it is a concept of public law known to legal systems across the world, particularly European legal systems:

Proportionality has ... been applied in public law around the world. A sophisticated model of the concept ... has emerged involving three aspects or levels. According to this doctrine, the government measure being reviewed must be suitable, necessary and not excessive in achieving its claimed end. ${ }^{23}$

The passage above is from an article by Jeremy Kirk which was published in a 1997 issue of the Melbourne University Law Review. His article still remains the leading academic reference for Australian audiences on the concept of proportionality. As the passage indicates, proportionality is a three-levelled concept, involving the sub-concepts of suitability, necessity, and balancing:

[T]hree preliminary steps must be taken before proportionality can be applied as a test of the validity of a government measure. Proportionality involves the balancing of competing interests. The competing interests in public law are the achievement of legitimate government ends and the protection of certain rights and interests from undue government regulation. The first two steps, therefore, are to identify each of these interests. The third step is to decide the level of intensity with which the test will be applied. For each level of proportionality it is possible to assess the requirements rigorously or deferentially. ${ }^{24}$

Suitability serves as an objective test of purpose. If a measure is not an effective, appropriate or rational means of achieving the claimed end, then the measure cannot reasonably be characterised as having been made to

\footnotetext{
${ }^{23}$ Kirk, above n 9, 4 .

${ }^{24}$ Ibid 4-5.
} 
achieve that end. Unless some other legitimate purpose emerges, the measure can be presumed to have been made predominantly for the impermissible purpose of restricting the relevant protected interest. ${ }^{25}$

The second level of proportionality involves assessing whether the measure is necessary in the sense that there are no alternative practicable means available to achieve the same end which are less restrictive of the protected interest. $^{26}$

Sometimes named proportionality in the narrow or strict sense, or proportionality properly so called, it is the third level which lies at the heart of the concept. It requires that the measure is either excessive or disproportionate in the sense that the restrictions or detriments caused outweigh the importance of the end or the beneficial result achieved ... On the detriment side, the extent of the restriction of a protected interest is relevant ... What is actually balanced is the significance of the detriment, which is a function of the level of restriction and the importance of the interest affected ... Similarly, on the other side of the equation, the importance of the end or value pursued by the measure has to be taken into account. So too does the benefit that the particular measure achieves in the context of that end. ${ }^{27}$

In summary, proportionality involves the reconciliation of principles or interests which conflict or are in tension. In public law these interests are the achievement of legitimate government ends and the protection of certain rights or interests. In this context, proportionality has been seen and applied as a tripartite concept, even if the components have sometimes not been acknowledged or properly understood. Whilst the three levels overlap somewhat, they remain logically distinct. ${ }^{28}$

Robust proportionality involves a cumulative sequence of analysis that tests the validity of the law or measure under challenge at three levels of assessment. These levels involve an inquiry into the 'suitability', 'necessity' and 'balancing' of that law or measure. This analysis seeks to establish whether a law or measure that a court has held to restrict some 'protected interest' should be declared valid notwithstanding its restriction.

\footnotetext{
${ }^{25}$ Ibid 6.

${ }^{26}$ Ibid 7 .

${ }^{27}$ Ibid 8 .

${ }^{28}$ Ibid 9.
} 
First, analysis of the 'suitability' of the law or measure under challenge involves an inquiry into whether it is an effective, appropriate, or rational means of pursuing the purpose driving that law or measure. ${ }^{29}$ The law or measure will meet the first criterion of suitability if the court is satisfied that it pursues a legitimate purpose. Normally, the court will deem a purpose legitimate as long as it responds to any consideration other than a desire to restrict the protected interest.

\section{$2 \quad$ Necessity}

Second, analysis of the 'necessity' of the law or measure under challenge involves an inquiry into whether there is an alternative means of pursuing the legitimate purpose that is less restrictive but, nonetheless, reasonably available. That is, necessity assesses the possibility of legislative choice. The law or measure will meet the second criterion of necessity if the court is satisfied that it has adopted the least restrictive means to pursue the particular purpose.

\section{$3 \quad$ Balancing}

Third, analysis of the 'balancing' of the law or measure under challenge involves a somewhat more difficult inquiry. It involves the court undertaking a cost-benefit analysis whereby the relative significance of the protected interest is weighted against the legitimate purpose pursued by the law or measure and, thereby, delimits the 'margin of appreciation,"30 or 'room for manoeuvre' allowed to the legislature. The law or measure will meet this third criterion if the court is satisfied that it strikes a reasonable and

\footnotetext{
29 Interestingly, the level of assessment that robust proportionality associates with the suitability of the law or measure under challenge coincides, to some extent, with the first limb of the test for determining whether a law infringes the constitutionally implied freedom of political communication, namely, 'does the law effectively burden freedom of communication about government or political matters either in its terms, operation or effect?' (Lange v Australian Broadcasting Corporation (1997) 189 CLR 520, 567-8). The test, however, has a second, more difficult limb, which, shrouded under the veil of balancing, denotes a concern with purpose akin to abridged proportionality: 'if the law effectively burdens that freedom, is the law reasonably appropriate and adapted to serve a legitimate end the fulfilment of which is compatible with the maintenance of the constitutionally prescribed system of representative and responsible government ...?' (ibid 567-8).

${ }^{30}$ The 'margin of appreciation' is a principle of the European Court of Human Rights: Handyside v United Kingdom (1976) 24 Eur Ct HR (ser A).
} 
justifiable balance between the interest and purpose. ${ }^{31}$ This level of assessment contains the core distinction between abridged proportionality and robust proportionality.

This concept of proportionality as involving a three-level inquiry (that is, into suitability, necessity, and balancing) is, for ease of reference, described by Amelia Simpson in the Federal Law Review as 'robust proportionality. ${ }^{32}$

\section{B Abridged Proportionality}

Robust proportionality is in contrast to abridged proportionality:

[T]he term 'abridged proportionality' [is used] to describe the narrower, alternative, conception in which proportionality analysis serves only to expose illegitimate legislative purposes. ${ }^{33}$

This latter concept is uniquely Australian and, in my opinion, describes the saving test that the Court formulated in Cole $v$ Whitfield and Castlemaine Tooheys Ltd v South Australia for section 92:

Australian constitutional jurisprudence seems to sustain a parallel, competing, model of proportionality analysis. This other model views the 'primary, and perhaps only, role of proportionality [as being] to assess whether a law can be characterised as achieving the claimed legitimate purpose. ${ }^{34}$

Implicit, then, in the concept of abridged proportionality is the judicial concern with the purpose of the law or measure under challenge. Already in Cole v Whitfield, the Court was resolute that its concern was with the purpose or, in the words of the Court, 'real object' of the law or measure. ${ }^{35}$

In Castlemaine Tooheys Ltd v South Australia, the Court continued to be concerned with purpose but masked its concern with the introduction of the 'appropriate and adapted' criterion ${ }^{36}$ as a kind of balancing exercise. Indeed, the Court concluded, at least seemingly, that if the effect of the law or measure under challenge is too extreme to achieve the purpose that the

\footnotetext{
${ }^{31}$ Amelia Simpson, 'Grounding the High Court's Modern Section 92 Jurisprudence: The Case for Improper Purpose as the Touchstone' (2005) 33 Federal Law Review 445, 456.

${ }^{32}$ Ibid 457.

${ }^{33}$ Ibid.

${ }^{34}$ Ibid (citations omitted).

${ }^{35}$ Cole v Whitfield (1988) 165 CLR 360, 408.

${ }^{36}$ Castlemaine Tooheys Ltd v South Australia (1990) 169 CLR 436, 472.
} 
legislature claims the law or measure to pursue, then such extremity may indicate that the law or measure pursues, in effect, another purpose altogether:

The fact that a law imposes a burden upon interstate trade and commerce that is not incidental or that is disproportionate to the attainment of the legitimate object of the law may show that the true purpose of the law is not to attain that object but to impose the impermissible burden. ${ }^{37}$

At least, in the above extract, the rationale of the Court seems to display some connexion between the suitability of the law under challenge and its balance, which is a level of assessment exclusive to robust proportionality. I do not believe, therefore, that the Court held the law under challenge in Castlemaine Tooheys Ltd $v$ South Australia invalid solely because of its purpose. Instead, I believe that the Court also considered the effect of the law. Almost twenty years later, the Court in Betfair Pty Ltd $v$ Western Australia took the opportunity to confirm this:

The promotion of litter control and of energy and resource conservation were propounded objects of the law which was held to fail in Castlemaine Tooheys. That law sought to achieve those objects by exempting refillable bottles from the requirement for the payment of a mandatory deposit. But this was no answer to the practical effect of the law which was held to be an impermissible discrimination of a protectionist kind against interstate trade. $^{38}$

I suggest, in summary, that the Court intertwined purpose and effect. In other words, the fact that the law under challenge had a protectionist effect indicated that its stated purpose was not its 'true purpose'. However, the 'balancing' level of assessment that robust proportionality calls for is a different exercise from the application of the 'appropriate and adapted' criterion that now comprises the second element of the saving test for section 92.

The two criteria are different because, insofar as the 'appropriate and adapted' criterion is concerned, the Court refuses to assess the desirability of the law or measure under challenge. Desirability, as a level of assessment, is the core distinction between abridged proportionality and robust

\footnotetext{
${ }^{37}$ Ibid (emphasis added).

38 Betfair Pty Ltd v Western Australia [2008] HCA 11 (27 March 2008) (Gleeson CJ, Gummow, Kirby, Hayne, Crennan, and Kiefel JJ) [47] (emphasis added). For a review of this case, please refer to the postscript below.
} 
proportionality. That is, the Court neither assesses the possibility of legislative choice nor delimits the margin of appreciation allowed to the legislature. In Castlemaine Tooheys Ltd $v$ South Australia, the Court expressly acknowledged its refusal thus: '[t]he question whether a particular legislative enactment is a necessary or even a desirable solution to a particular problem is in large measure a political question best left for resolution to the political process. ${ }^{39}$

Unfortunately, this masked judicial concern with the purpose of the law or measure under challenge is to the detriment of any judicial inquiry into the actual effect of the law or measure. Undue attention to the purpose of the law or measure under challenge is one of the two difficulties that the current saving test for section 92 raises.

\section{Proportionality ANd the Federal Purpose of SECTION 92 OF the Australian Constitution}

Before I discuss this difficulty, it is necessary to understand the flawed understanding of proportionality that the majority judgment in Castlemaine Tooheys Ltd v South Australia displays, both relative to the concept of robust proportionality and in light of the federal purpose of section 92 of the Australian Constitution. The rationale against abridged proportionality is not complicated. It revolves around the idea that abridged proportionality may validate laws or measures that are seemingly compatible with the common market, insofar as their claimed purpose is concerned, but that, in effect, compromise the absolute freedom of interstate trade and commerce that section 92 guarantees. Therefore, in my opinion, a law or measure should be invalid if alternative non-discriminatory means to pursue the legitimate purpose are possible. ${ }^{40}$ Discrimination is inadmissible irrespective of purpose, aim, or intent:

Where the rationale underpinning a non-discrimination norm is the pursuit of economic wellbeing it makes good sense that unintended protectionist discrimination be caught within the norm's scope, for the relevant harm is not lessened by the absence of intent. ${ }^{41}$

Robust proportionality does not have the flaws of abridged proportionality. This fuller concept of proportionality represents a solid foundation for a saving test that would reflect the vision of a common market that the

\footnotetext{
${ }^{39}$ Castlemaine Tooheys Ltd v South Australia (1990) 169 CLR 436, $472-3$ (emphasis added).

${ }^{40}$ Kirk, above n 9, 20.

${ }^{41}$ Simpson, above n 31, 477 (emphasis added).
} 
founders had and entrusted to section 92. It looks beyond the purpose of the law or measure under challenge into the effect that it actually has on the common market and on interstate competition:

The robust proportionality account of section 92 accepts that a finding of discriminatory protectionist purpose will be a sufficient condition for invalidity. But the account does not regard such a finding as a necessary condition for invalidity - some laws will transgress section 92 even in the absence of improper purpose. In particular, a robust proportionality account presumes that the High Court sees unintended protectionist discrimination as potentially invalid under section $92 .^{42}$

The founders intended that the effect of a law or measure should warrant the same consideration as its purpose. Proof of their intention is that the pre-1900 decisions of the Supreme Court of the United States of America on the Commerce Clause in the United States Constitution influenced the Australian founders when they deliberated the terms of section $92^{43}$ and those decisions did gave greater weight to effect than to purpose. For example, in the United States case of Minnesota $v$ Barber, ${ }^{44}$ Harlan J stated:

A burden imposed by a State upon interstate commerce is not to be sustained simply because the statute imposing it applies alike to the people of all the States, including the people of the State enacting such statute. ... The people of Minnesota have as much right to protection against the enactments of that State, interfering with the freedom of commerce among the States, as have the people of other States. Although this statute is not avowedly, or in terms, directed against the bringing into Minnesota of the products of other States, its necessary effect is to burden or obstruct commerce with other States, as involved in the transportation into that State, for purposes of sale there, of all fresh beef, veal, mutton, lamb or pork, however free from disease may have been the animals from which it was taken. ${ }^{45}$

Thus, inspired by Minnesota v Barber and its precedent, Guy v Baltimore, ${ }^{46}$ Henry Parkes, then Premier of New South Wales, stated on 10 February 1890 at the preliminary Australasian Federation Conference:

\footnotetext{
${ }^{42}$ Ibid 458 (emphasis added).

${ }^{43}$ J A La Nauze, 'A Little Bit of Lawyers' Language: The History of "Absolutely Free" 18901900' in A W Martin (ed) Essays in Australian Federation (1969) 57, 69.

${ }^{44}$ (1890) 136 US 313.

${ }^{45}$ Minnesota v Barber (1890) 136 US 313, 326 (Harlan J) (emphasis added). Interestingly, in one of the first cases on s 92, Barton $\mathrm{J}$ referred to the effect of the law under challenge in Duncan v Queensland (1916) 22 CLR 556, 598.

${ }^{46}$ (1879) 100 US 434.
} 
The case seems to set at rest, in the most emphatic manner, what is sometimes disputed - the question of existence of entire freedom throughout the territory of the United States. As the members of the Conference know, she has created a tariff of a very severe, and in some cases almost prohibitive character against the outside world; but as between New York and Massachusetts, and as between Connecticut and Pennsylvania, there is no custom house and no tax collector. Between any two of the States indeed from one end of the States to the other - the country is as free as the air in which the swallow flies. We cannot too fully bear in mind this doctrine of the great republic, a doctrine supported in the most convincing manner by the case to which I have alluded. ${ }^{47}$

Earning his title as the 'Father of Federation', Parkes submitted a draft of the resolutions that he believed delegates ought to put before the National Australasian Convention. His first resolution, 'which by taking pride of place shows the importance which he attached to making Australia one "free-trade" unit', ${ }^{48}$ read:

That the trade and intercourse between the Federated Colonies, whether by means of land carriage or coastal navigation, shall be free ... from all restrictions whatsoever, except such regulations as may be necessary for the conduct of business. ${ }^{49}$

As the earliest recorded expression of the federal purpose of section 92, this resolution is powerful evidence of the vision of a national market for regional produce that the founders projected on section 92. Robust proportionality secures that vision of a common market.

Like Kirk, therefore, I argue that robust proportionality represents the strongest conceptual foundation for a test of legitimate restriction. Suitability, necessity, and balancing should be the criteria that form the basis of the saving test for section 92:

\footnotetext{
${ }^{47}$ Official Record of the Proceedings and Debates of the Australasian Federation Conference, Melbourne, 10 February 1890, 46 (Henry Parkes) (emphasis added).

${ }^{48}$ F R Beasley, 'The Commonwealth Constitution: Section 92 - Its History in the Federal Conventions' (1948-50) 1 University of Western Australia Annual Law Review 97, 98.

${ }^{49}$ Henry Parkes, Fifty Years in the Making of Australian History (1892) vol 2, 359 (emphasis added). The recognition that this resolution makes of the need for genuine regulation of intrastate and interstate trade and commerce contradicts the opinion of Sawer who once observed that 'Parkes admired laissez-faire as much as he did free trade' (Geoffrey Sawer, 'Constitutional Law' in George W Paton (ed), The Commonwealth of Australia: The Development of its Laws and Constitution (1952) 71, 76). In his opinion, 'most of the Founders were also devotees of "free trade" in the more extensive sense of minimum regulation for commercial activities' (Michael Coper, Encounters with the Australian Constitution (1988) 273-4).
} 
First, each of the three levels of the concept serves a justified role in this context. The restriction of constitutional guarantees can only be supported if a measure is made in pursuance of a genuine competing legitimate purpose. The first level of proportionality tests whether a measure can be characterised as pursuing such a purpose. If it is accepted that a constitutionally protected interest can sometimes be overridden by competing public interests, but that not just any public interest or any set of circumstances can justify such restriction, then the need for a balancing test becomes plain. ... This need to draw a balance is given effect by third level proportionality. The second level of proportionality reflects the view that, even if on balance the restriction is justified, to accord full and substantive respect to the guarantee demands that it be restricted as little as possible. A measure will therefore be invalid if alternative practicable means of achieving the legitimate end are available.

Secondly, a proportionality test facilitates the provision of clear and detailed reasons for any decision as to a law's validity. ... The exact objection to a restriction is more likely to emerge from a reasoned application of proportionality. ...

Thirdly, the test is sufficiently flexible to cope with any type of constitutional guarantee or any range of circumstances. ${ }^{50}$

The virtues of robust proportionality are universally recognised. Proof of its wide acceptance is the adoption of three-levelled proportionality by the European Court of Justice. Indeed, proportionality is, in origin, a principle of German public law. The European Court of Justice acknowledged it as a general principle of European Community law in Internationale Handelsgesellschaft $v$ Einfuhr- und Vorratsstelle für Getreide und Futtermittel (Solange I), ${ }^{51}$ in which Advocate General de Lamothe stated that 'the individual should not have his freedom of action limited beyond the degree necessary in the public interest'. ${ }^{2}$ The European Court of Justice subsequently expanded the principle of proportionality in $R v$ Minister of Agriculture, Fisheries and Food ex parte Fedesa. ${ }^{53}$ The academic consensus is that the principle of proportionality, as a general principle of European Community law, comprises a test of suitability, a test of necessity, and a test of desirability. ${ }^{54}$ Notably, the European Court of Human Rights, ${ }^{55}$ Supreme

\footnotetext{
${ }^{50}$ Kirk, above n 9, 19-20 (emphasis added).

${ }^{51}$ (C-11/10) [1970] ECR 1125.

${ }^{52}$ Ibid 1147 (emphasis added).

53 (C-331/88) [1990] ECR I-4023.

${ }^{54}$ See Gráinne de Búrca, 'The Principle of Proportionality and its Application in EC Law' (1993) 13 Yearbook of European Law 105, 113. See also Takis Tridimas, The General Principles of EC Law (1999) 91-3.
} 
Court of Canada ${ }^{56}$ and Hong Kong Court of Appeal ${ }^{57}$ have followed suit and adopted robust proportionality. ${ }^{58}$

Unfortunately, the High Court of Australia has been reluctant to adopt robust proportionality:

It is unfortunate that ... no member of the High Court has yet clearly recognised the three level nature of proportionality. The structured approach of proportionality represents a beneficial addition to Australian constitutional law in this context. ${ }^{59}$

This reluctance is somewhat odd given that, in the 1970s, cases on section 92 witnessed attempts by several judges of the Court to develop an Australian approach to the three levels of assessment that characterise robust proportionality. For example, in Uebergang $v$ Australian Wheat Board, Stephen and Mason JJ emphasised that their imagined saving test for section 92 required balancing the adverse effect on interstate trade and commerce with the 'need which is felt for the regulation'. ${ }^{60}$

In addition, their Honours indicated that a court could indeed declare the law or measure under challenge unconstitutional if there were alternative and practicable means of pursuing the purpose with a less adverse effect on interstate trade and commerce. It is evident from their judgment that Stephen and Mason JJ were thinking in terms of the second and third levels of robust proportionality. ${ }^{61}$

Academic commentators too have expressed support for a more robust concept of proportionality as the doctrinal basis for the saving test. For example, some years ago, Leslie Zines advocated the third level of assessment that balances suitability against necessity:

While the court has declared that it is not its concern to determine the social benefits or otherwise of legislation that impinges on interstate trade, it is clear that a degree of balancing of social interests, in some cases at any rate, is inevitable. ${ }^{62}$

\footnotetext{
${ }^{55}$ Handyside v United Kingdom (1976) 24 Eur Court HR (ser A) [42]-[50].

${ }^{56} R v$ Oakes [1986] 1 SCR 103, 138-40.

${ }^{57} R v$ Sin Yau Ming [1992] 1 HKCLR 127, 145.

${ }^{58}$ Kirk, above $\mathrm{n} 9,4$.

${ }^{59}$ Ibid 20 (emphasis added).

${ }^{60}$ Uebergang v Australian Wheat Board (1980) 145 CLR 266, 306 (Stephen and Mason JJ).

${ }^{61}$ Kirk, above n 9, 13.

${ }^{62}$ Leslie Zines, The High Court and the Constitution (4 ${ }^{\text {th }}$ ed, 1997) 152 (emphasis added).
} 
Zines, thus, regretted the refusal of the Court to assess the desirability of the law or measure under challenge as tantamount to a refusal to undertake the cost-benefit analysis implicit in the third level of assessment that defines robust proportionality.

Similarly, albeit not necessarily invoking the elements of suitability and necessity, Michael Coper defended the need to balance when he recognised that 'in the case of section 92 there is no escape from the need to strike a balance between competing national and local interests. ${ }^{63}$ Sadly, the 'appropriate and adapted' criterion of Castlemaine Tooheys Ltd v South Australia is not a balancing exercise. It is nothing but a formula for abridged proportionality because it avoids assessing the desirability of the law or measure under challenge.

Against such judicial precedent and academic commentary, it is unfortunate that the Court in Cole $v$ Whitfield and later in Castlemaine Tooheys Ltd $v$ South Australia rejected the three-level understanding of proportionality. In fact, reflecting on the evolution of the concept of proportionality in Australia, Kirk expressed his regret that Castlemaine Tooheys Ltd v South Australia halted the promising progress made up to, and including, Uebergang $v$ Australian Wheat Board, towards the development of robust proportionality:

The s 92 cases show that proportionality has deep roots in Australia. By 1980 a test for legitimate restriction of s 92 had evolved which incorporated both the second and third levels of the concept (which in turn presuppose the first level). In one sense, therefore, Castlemaine added little but the label. Indeed, in so far as the court in that case did not ... articulate the different aspects of proportionality, the Castlemaine test is arguably less clear than the approach of Stephen and Mason JJ in Uebergang. ${ }^{64}$

Not all is lost. There is still hope that the Court will revise its abridged understanding of proportionality as the doctrinal basis for the section 92 saving test and proceed to fortify it with the three levels of assessment that underpin robust proportionality. As recently as 2004, in the case of Permanent Trustee Australia Ltd v Commissioner of State Revenue (Vic), ${ }^{65}$ a majority of the Court approached a constitutional non-discrimination norm similar to the norm that I propose for section 92 in a way seemingly

\footnotetext{
${ }^{63}$ Michael Coper, Commonwealth of Australia, The Curious Case of the Callow Crayfish: The New Law Relating to Section 92 of the Australian Constitution, Parliamentary Library Discussion Paper No 1 (1989-90) 2, 24 (emphasis added).

${ }^{64}$ Kirk, above n 9, 15-6.

${ }^{65}$ (2004) 220 CLR 388.
} 
supportive of the robust proportionality approach. ${ }^{66}$ That is, the Court appeared to demonstrate a greater concern with the effect of the law or measure under challenge than is customary. Indeed, signals such as those coming from Permanent Trustee Australia v Commissioner of State Revenue (Vic) have been picked up by Simpson who has noted that 'the High Court has, in various constitutional contexts, introduced a concept of proportionality inspired by the three-level doctrine prevalent in European Courts. ${ }^{67}$

\section{Purpose Versus Effect}

I mentioned earlier that the test of legitimate restriction that the High Court of Australia developed in Cole v Whitfield and Castlemaine Tooheys Ltd v South Australia as an antidote to a finding of discriminatory protectionism has two doctrinal flaws.

\section{A Introduction}

One flaw is that the legitimate restriction test is far too weak to preserve the common market that the founders devised as the federal purpose of section 92 of the Australian Constitution. After all, it is a mere abridgment of the concept of robust proportionality. It is an abridgment because the test stops at the first level of assessment, pertaining to the suitability of the law or measure under challenge, and does not continue to the second and third levels of assessment, involving necessity and balancing. In truth, this flaw merges, almost indistinguishably, with the second of the two doctrinal flaws that lie at the core of the current saving test for section 92. The reason for this second flaw, like for the first, is the inconsistency of abridged proportionality with the federal purpose intended by the founders for section 92 .

This flaw, which directly stems from the first, is that the test is concerned with the purpose and not so much with the effect of the law or measure under challenge. In practice, this approach implies that a law or measure that has a purpose that is not discriminatory in a protectionist kind can be held to comply with section 92 even though the effect of the law or measure violates the common market.

\footnotetext{
${ }^{66}$ Permanent Trustee Australia Ltd v Commissioner of State Revenue (Vic) (2004) 220 CLR 388. See also Simpson, above n 31, 462.

${ }^{67}$ Simpson, above $\mathrm{n} 31,456$.
} 


\section{B Abridged Proportionality and its Concern with Legislative Purpose}

The purpose-driven dynamic evident in the saving test introduced in Cole $v$ Whitfield and later ratified in Castlemaine Tooheys Ltd $v$ South Australia is integral to the concept of abridged proportionality. Abridged proportionality offers a reading of section 92 that is not robust enough to uphold the vision that the founders had of a common market absolutely free from discrimination of any kind. There is, therefore, a very strong need to denounce the fatally flawed mode of reasoning that impregnates the current saving test for section 92 .

\section{$1 \quad$ Judicial Construction of Legislative Purpose}

Such is the concern of the Court to look into the purpose of the law or measure under challenge that it is prepared to go to the length, absurd in my opinion, of reading a purpose where none is apparent from the law or measure itself. That is, the current saving test for section 92 is stretched by the Court to the limit so as to try to draw a purpose from the law or measure under challenge, even if no purpose is expressed:

In the presumably certain absence of any declaration in legislation that it had a protectionist purpose, it would be necessary ... to consider whether such a purpose could reasonably be inferred from the terms of the legislation and all relevant circumstances at the time of the decision. ${ }^{68}$

This persistent reference to the purpose of the law or measure blinds the Court to the effect of the law even where the purpose is not readily apparent. This is a somewhat curious and paradoxical circumstance because, in the end, the reality is that it is only the effect of the law or measure that can be empirically quantified. Unlike purpose, effect is not measured in words but in actions. Effect is palpable and tangible. Purpose is not.

I acknowledge that effect could be an evidentiary question of some difficulty to answer. Indeed, future section 92 cases are likely to raise highly complex problems of proof concerning the factual operation of the law or measure under challenge:

The [High] Court has not fully addressed the fact finding processes by which factual discrimination or protectionism must be proved, at least

${ }^{68}$ Dennis J Rose, 'Cole $v$ Whitfield: "Absolutely Free" Trade?' in H P Lee and George Winterton (eds), Australian Constitutional Landmarks (2003) 335, 346 (emphasis added). 
where the issues are contested. In Cole $v$ Whitfield and Castlemaine Tooheys, the Court was fortunate to have agreed statement of facts between the parties. ${ }^{69}$

In other words, when the allegation made before the Court is that the law or measure under challenge is protectionist because it discriminates in its operation, the probability that the parties to the dispute will submit an agreed statement of facts is, at best, negligible. ${ }^{70}$

Inevitably, without reference to an agreed statement of facts, the Court will encounter a laborious, difficult, and definitely unenviable fact-finding process, which it is neither sufficiently experienced nor sufficiently resourced to undertake. Nonetheless, while the effect of a law or measure could be, in a few cases, an evidentiary question that is difficult to answer, it is, ultimately, measurable in real terms. Purpose, however, can never transcend a mere verbal formula. Therefore, academic commentators have suggested a number of solutions to the evidentiary problem that the determination of effect can present.

One suggestion relates to the type of evidence that the Court should require parties to submit in section 92 cases. Staker has argued that the problem of establishing protectionism would be solved if the Court insisted on hearing expert evidence about relevant economic concepts such as, for example, the cross-elasticity of demand between competing interstate goods:

One solution might be to respond by forging appropriately complex economic tests, and require comprehensive expert evidence to be given on the actual 'cross-elasticity of demand' between the interstate product affected by a law and the domestic product alleged to be in competition with it. $^{71}$

Expert evidence given by both academic and practising economists would be of much assistance to the Court since section 92 cases revolve around

\footnotetext{
${ }^{69}$ Michael Coper, 'Freedom of Interstate Trade and Commerce', in Tony Blackshield, Michael Coper, and George Williams (eds), The Oxford Companion to the High Court of Australia (2002) 354, 356 (emphasis added). See generally Zines, above n 62, 471-82.

${ }^{70}$ Andrew S Bell, 'Section 92, Factual Discrimination and the High Court' (1991) 20 Federal Law Review 240, 246.

${ }^{71}$ Staker, above n 22, 345 (emphasis added). See also Customs Act 1901 (Cth) s 269B(4) and Corinthian Industries (Syd) Pty Ltd v Comptroller-General of Customs (1989) 86 ALR 387; Amcor Ltd v Comptroller-General of Customs (1988) 79 ALR 221; Davies Craig Pty Ltd v Comptroller-General of Customs (1986) 68 ALR 105.
} 
inherently economic concepts such as protectionism and competitive advantage:

Given that the identification of a market is logically antecedent to any examination of market advantage, then, as experience in relation to Part IV of the Trade Practices Act 1974 (Cth) illustrates, the importance of the role of economic expertise in assisting the Court cannot be gainsaid. ${ }^{72}$

Given the lack of technical expertise among members of the Court, academic commentators have put forward further solutions in relation to the type of forum where judges can best hear expert evidence:

[T] he difficulties which attend the reception of evidence germane to the question of whether s 92 has been infringed leads one to consider whether s 92 cases should be heard by either a single High Court Justice at first instance or remitted to the Federal Court under s 44(1) of the Judiciary Act 1903 (Cth). ${ }^{73}$

A similar, but perhaps more sensible, solution has been suggested in several quarters, including the Constitutional Commission of $1988 .^{74}$ It calls for the restoration of the Inter-State Commission. Coper has been its staunchest advocate:

The link [between the decision in Cole $v$ Whitfield and the potential role of the Inter-State Commission] is simply this: the proper resolution of issues that turn on the presence or absence of [discriminatory protectionism] against interstate trade requires thorough factual investigation and the Constitution contemplates that the Inter-State Commission will play an appropriate role. $^{75}$

As the above passage mentions, the Inter-State Commission is indeed established by the Constitution, more particularly by section 101. Various academic commentators have proposed that the Inter-State Commission, which the Commonwealth government last dissolved in 1989, could be responsible for the resolution of factual questions involving the often

\footnotetext{
${ }_{72}^{72}$ Bell, above n 70, 246 (emphasis added).

${ }^{73}$ Ibid 250 (emphasis added).

${ }^{74}$ Commonwealth, Constitutional Commission, Final Report of the Constitutional Commission (1988) 838-45.

${ }^{75}$ Michael Coper, 'The Second Coming of the Fourth Arm: The Role and Functions of the Inter-State Commission' (1989) 63 The Australian Law Journal 731, 744-5 (emphasis added). Ironically, Coper was one of the members of the Inter-State Commission before it was most recently dissolved.
} 
technical and voluminous economic evidence that parties submit before the Court in section 92 cases. $^{76}$

The determination of the effect of a law or measure under challenge can, as I have explained, be a problem. However, it is not, as I have also explained, a problem without solutions. In my opinion, therefore, the bigger problem would be the risk to the integrity of the common market posed by the continuation of a saving test that is concerned with the purpose and not with the effect of the law or measure under challenge. Such is its concern for purpose that the saving test risks saving laws or measures that have a discriminatory effect against interstate trade and commerce if they have a purpose that is not protectionist.

\section{Evidence from the Cases}

Proof of the judicial concern for purpose, to the detriment of effect, is widespread in the judgments from the two now leading cases on section 92 . For example, the joint judgment that the Court handed down in Cole $v$ Whitfield includes numerous remarks indicative of a concern with the purpose of the law or measure under challenge. The Court itself indicated that its concern was with the 'real object', not the effect, of the law or measure. ${ }^{77}$

Unable to find discrimination in a protectionist sense, the Court in Cole $v$ Whitfield was content with evidence that 'no discriminatory protectionist purpose appears on the face of the [impugned] law. ${ }^{78}$ As absurd a premise as it may seem, to the Court, protectionist effect can be tantamount to constitutional validity. ${ }^{79}$

The theory of section 92 that the Court advanced in Cole $v$ Whitfield was affirmed two years later. Indeed, Castlemaine Tooheys Ltd v South Australia confirmed the suspicion that the preceding case aroused, that the Court actually does require the law or measure under challenge to have an identifiable protectionist purpose before it is invalidated as being discriminatory in a protectionist sense:

\footnotetext{
${ }^{76}$ Simpson, above n 31, 480; Richard Cullen, 'Section 92: Quo Vadis?' (1989) 19 University of Western Australia Law Review 90, 123; M Coper, Commonwealth of Australia, The Curious Case of the Callow Crayfish: The New Law Relating to Section 92 of the Australian Constitution, Parliamentary Library Discussion Paper No 1 (1989-90) 2, 29; Bell, above n 70 , 251.

${ }^{77}$ Cole v Whitfield (1988) 165 CLR 360, 408.

${ }^{78}$ Ibid 409.

${ }^{79}$ Ibid 408. See also Simpson, above n 31, 453.
} 
[W]here a law on its face is apt to secure a legitimate object but its effect is to impose a discriminatory burden upon interstate trade as against intrastate trade, the existence of reasonable non-discriminatory alternative means of securing that legitimate object suggests that the purpose of the law is ... to effect a form of prohibited discrimination. There is also some room for a comparison, if not a balancing, of means and objects in the context of s 92 . The fact that a law imposes a burden upon interstate trade and commerce that is not incidental or that is disproportionate to the attainment of the legitimate object of the law may show that the true purpose of the law is not to attain that object but to impose the impermissible burden. ${ }^{80}$

The passage above demonstrates that the emphasis on purpose is attributable to the application of abridged proportionality as a saving test for section 92 . Indeed, there are various passages in the majority judgment in Castlemaine Tooheys Ltd $v$ South Australia that reveal the over-zealous concern that the Court has for purpose as a measure of the legitimacy of legislative and executive regulation of interstate trade and commerce. This emphasis on purpose is in contrast to the robust concept of proportionality.

One, if perhaps indirect, criticism of the concern for purpose that the Court shows in its application of the saving test for section 92 can be found in the minority judgment that Gaudron and McHugh JJ handed down in Castlemaine Tooheys Ltd $v$ South Australia. Their Honours rejected as incomplete the saving test favoured by the majority. In the view of Gaudron and $\mathrm{McHugh} \mathrm{JJ}$, abridged proportionality, driven as it is by purpose, may not filter laws or measures whose 'practical effect is protectionist' if their purpose is not protectionist:

Thus, if there is no inequality or relevant difference between the subject matter of interstate trade and the subject matter of intrastate trade, a law which is appropriate and adapted to an objective and burdens interstate trade only incidentally and not disproportionately to that objective will, in our view, offend against $s 92$ if its practical effect is protectionist particularly if there exist alternative means involving no or a lesser burden on interstate trade. ${ }^{81}$

It is clear that Gaudron and McHugh JJ believed that section 92 should catch laws and measures that may not be protectionist in purpose but are,

\footnotetext{
${ }^{80}$ Castlemaine Tooheys Ltd v South Australia (1990) 169 CLR 436, 471-2 (Mason CJ, Brennan, Deane, Dawson, and Toohey JJ) (emphasis added). See also Simpson, above n 31, 454 .

${ }^{81}$ Castlemaine Tooheys Ltd v South Australia (1990) 169 CLR 436, 480 (Gaudron and McHugh JJ) (emphasis added).
} 
nonetheless, protectionist in effect. In the words of one academic commentator, 'section 92 must be presumed to extend beyond intentional burdens and also to target burdens that are inadvertent yet unjustified. ${ }^{82}$ Simply, Gaudron and McHugh JJ wished to make the point that section 92 is also concerned with unintended effects. The fact that their Honours felt it necessary to differentiate their approach from that followed by the majority reveals that the saving test for section 92 used by the majority is concerned only with inferring the purpose of the law or measure under challenge.

\section{A Looser and Instrumental Use of Facts}

The saving test for section 92 is overly concerned with the purpose of the law or measure under challenge as the criterion of constitutional legitimacy. A saving test that focuses on purpose alone implies a 'looser, instrumental, use of facts' that a saving test that focuses on purpose and effect. ${ }^{83}$ That is, with such a saving test, the Court can afford to disregard the attestable, even perhaps protectionist, realities of the case and, instead, simply rely on the purpose evident on the face of the law or measure under challenge as the only indispensable fact. Consequently, the Court does not have the capacity to tailor decisions to the particularities of the real world. A saving test that validates laws or measures that do not have a protectionist purpose but that, nonetheless, have a protectionist effect is nothing but absurd. ${ }^{84}$ The founders definitely did not contemplate such absurdity. Through section 92, the founders sought an efficient common market free from discrimination against interstate trade and commerce, irrespective of whether that discrimination was deliberate or not.

\section{Conclusion}

I argue that abridged proportionality as a saving test for section 92 is doctrinally flawed. It is flawed because it does not reflect the vision that the founders had of a national market for local produce. Abridged proportionality lacks the second and third levels of assessment that make the concept of proportionality robust, and is simply concerned with the purpose of the law or measure under challenge. As important a consideration as it may be, purpose is only one side of the coin. The other side of the coin, namely the effect of the law or measure under challenge, can be an equally disruptive

\footnotetext{
${ }^{82}$ Simpson, above n 31, 461 (emphasis added).

${ }^{83}$ Ibid 483.

${ }^{84}$ The only merit to the absurdity of the saving test would concern cases of threatened risk, such as a situation where the entry of potentially diseased goods from another State must be stopped.
} 
variable with the potential to hamper the absolute freedom of interstate trade and commerce that section 92 guarantees.

The founders envisioned a common market free from the influence of legalistic technicalities and semantic nuances. The distinction between purpose and effect is largely doctrinal and, as such, elusive to measurable standards. Yet, to ignore effect as a consideration is an open invitation to the State and Commonwealth governments to develop laws and measures that, in form, are compatible with the common market but, in substance, are inconsistent with it. Realistically, assessment of the suitability of the law or measure can only uncover the purpose of the law or measure. To uncover the effect of the law or measure, its necessity must be assessed and then balanced against its suitability. Only, robust proportionality can do this.

\section{CONCLUSION}

In conclusion, my doctrinal critique of abridged proportionality takes the form of a comparison of it with robust proportionality. The comparison reveals that the test of abridged proportionality requires the High Court of Australia to assess the suitability of the law or measure under challenge. In order to undertake that assessment, despite the contrary implication of the 'appropriate and adapted' criterion of Castlemaine Tooheys Ltd v South Australia, the Court needs only to analyse the purpose of the law or measure. By contrast, the test of robust proportionality requires the Court to assess not only the suitability but also the necessity of the law or measure and the balance between the freedom in section 92 of the Australian Constitution and the restriction of that freedom by the law or measure. In order to undertake that assessment, the Court needs to analyse both the purpose and the effect of the law or measure under challenge. By implication, therefore, the test of abridged proportionality risks saving laws or measures that have a discriminatory effect on interstate trade and commerce if they have a purpose that is not protectionist. Accordingly, I argue that abridged proportionality cannot preserve the common market with the same level of strength that robust proportionality has. Furthermore, I argue that the concern of the test of abridged proportionality with the purpose of the law or measure under challenge is problematic because it implies a looser and instrumental use of facts. Thus, I argue for robust proportionality and criticise the reluctance of the Court to introduce the concept even though there is judicial precedent and academic commentary in support of its introduction. 


\section{POSTSCRIPT}

Twenty years ago, in Cole $v$ Whitfield, the High Court of Australia resolved to develop a definitive test for section 92 of the Australian Constitution. The Court further developed the Cole $v$ Whitfield test in three cases between 1988 and 1990, namely, Bath v Alston Holdings Pty Ltd, ${ }^{85}$ Castlemaine Tooheys Ltd v South Australia, and Barley Marketing Board (NSW) v Norman. ${ }^{86}$

The Court did not again apply the Cole $v$ Whitfield test until earlier this year when, on 27 March 2008, the Court handed down its judgment in Betfair Pty Ltd $v$ Western Australia:

All parties accept as the source of present doctrine respecting s 92 what was said 20 years ago in Cole $v$ Whitfield and further developed and applied in the authorities decided shortly thereafter, namely Bath $v$ Alston Holdings Pty Ltd, Castlemaine Tooheys Ltd v South Australia and Barley Marketing Board (NSW) v Norman. ${ }^{87}$

The Court not only applied the test but also developed it. Curiously, the reasons for its development read like a response to this article and its critique of the Cole $v$ Whitfield saving test for section 92.

This article argued that, despite its acceptance of abridged proportionality as the saving test, the Court should assess not only the suitability but also the necessity and balance of the law or measure under challenge. Through a more robust concept of proportionality, the Court would analyse not only the purpose but also the effect of the law or measure.

In Betfair Pty Ltd v Western Australia, the Court formally incorporated the criterion of 'reasonable necessity' into the 'appropriate and adapted' criterion that the Court had expressed in Castlemaine Tooheys Ltd v South Australia:

[T]he 'appropriate and adapted' criterion expressed in Castlemaine Tooheys ... must give significant weight to the considerations referred to earlier in these reasons ... These involve the constraint upon market forces operating within the national economy by legal barriers protecting the domestic producer or trader against the out-of-State producer or trader, with consequent prejudice to domestic customers of that out-of-State producer or trader. They suggest the application here, as elsewhere in constitutional,

\footnotetext{
${ }^{85}$ (1988) 165 CLR 411.

${ }^{86}$ (1990) 171 CLR 182.

${ }^{87}$ Betfair Pty Ltd v Western Australia [2008] HCA 11 (27 March 2008) (Gleeson CJ, Gummow, Kirby, Hayne, Crennan, and Kiefel JJ), [47] (emphasis added).
} 
public and private law, of a criterion of 'reasonable necessity'. For example, in North Eastern Dairy Co Ltd v Dairy Industry Authority of NSW, Mason J said:

'As the defendant has failed to show that the discriminatory mode of regulation selected is necessary for the protection of public health, it is in my judgment not a reasonable regulation of the interstate trade in pasteurized milk.'

His Honour also referred to remarks in a similar vein by the Privy Council in The Commonwealth $v$ Bank of NSW.

That view of the matter should be accepted as the doctrine of the Court. It is consistent with the explanation given in Cole $v$ Whitfield of the justification of the total prohibition in the Tasmanian legislation on the sale of all undersized crayfish, irrespective of origin, as supplied by its objective of the conservation of the stock of Tasmanian crayfish. The Court held that the prohibition was a 'necessary means of enforcing the prohibition against the catching of undersized crayfish in Tasmanian waters' because that State 'cannot undertake inspections other than random inspections and the local crayfish are indistinguishable from those imported from South Australia'. ${ }^{88}$

On the basis of this reformulation of the saving test for section 92, the Court concluded:

$[\mathrm{T}]$ he prohibitory State law is not proportionate; it is not appropriate and adapted to the propounded legislative object. ... [I] $\mathrm{t}$ cannot be found in this case that prohibition was necessary in the stated sense for the protection or preservation of the integrity of the racing industry. ... [T] he means adopted, prohibition, was not appropriate and adapted to achieve [the protection of the integrity of the racing industry in Western Australia] given the avenue of regulation in a non-discriminatory manner. ${ }^{89}$

Notably, the last line in the last of the above extracts implies that the law or measure under challenge should be invalid if 'alternative ... effective but non-discriminatory' means to pursue the legitimate purpose are possible. ${ }^{90}$ Thus, the Court now accepts the need to assess the possibility of legislative choice. $^{91}$ Sadly, however, the third and definitive level of assessment (balancing) remains absent from the reasoning of the Court. Nevertheless,

\footnotetext{
${ }^{88}$ Ibid [101]-[103] (emphasis added).

${ }^{89}$ Ibid [110], [112]-[113] (emphasis added).

${ }^{90}$ Ibid [110].

${ }^{91}$ Ibid [110], [112].
} 
after Betfair Pty Ltd v Western Australia, the Cole v Whitfield saving test for section 92 is only one level away from robust proportionality.

Notwithstanding its refusal to balance the relative significance of the protected interest against the legitimate purpose pursued by the law or measure, the Court did refer to the 'practical effect' of the law under challenge. ${ }^{92}$ Clearly, the period between the case of Cole $v$ Whitfield in 1988 and the case of Betfair Pty Ltd v Western Australia in 2008 moderated the persistent concern with purpose that the Court had earlier shown. At least the Court now formally recognises the effect of a law or measure under challenge as a legitimate consideration in the application of the saving test for section 92:

[A] law the practical effect of which is to discriminate against interstate trade in a protectionist sense is not saved by the presence of other objectives such as public health which are not protectionist in character. ${ }^{93}$

Before Betfair Pty Ltd v Western Australia, the Court did not refer to the effect of the law or measure under challenge in its reasons for fear of departure from the purposive saving test that Cole $v$ Whitfield had dictated for section 92. It is true that the determination of the facts in cases such as Castlemaine Tooheys Ltd $v$ South Australia compelled the Court to assess, albeit under cover, the effect of the law or measure under challenge; but the Court would never do so openly. Betfair Pty Ltd v Western Australia was a refreshingly different case. Hence, the Court concluded:

The effect of the legislation of Western Australia is to restrict what otherwise is the operation of competition in the stated national market by means dependent upon the geographical reach of its legislative power within and beyond the State borders. This engages s 92 of the Constitution. ${ }^{94}$

The Court even admitted that the invocation of non-protectionist purposes would no longer save a law from invalidity under section 92 if its effect were indeed protectionist:

The Commonwealth, as intervener, submitted that it is sufficient for validity of a law if one of several objectives is non-protectionist. That submission is inconsistent both with Castlemaine Tooheys and with the United States decisions before federation which influenced the framing of $\mathrm{s} 92$. If accepted, the Commonwealth submission would impermissibly weaken the

\footnotetext{
92 Ibid [47]-[48].

${ }^{93}$ Ibid [47] (emphasis added).

94 Ibid [116] (emphasis added).
} 
force of the imperative demand of s 92 . It would do so by allowing to stand legislation which imposes upon interstate trade a discriminatory burden of a protectionist kind, merely because of the presence of other objectives. ${ }^{95}$

Hopefully, another 20 years will not elapse before the High Court of Australia applies what is now a European saving test for section 92 of the Australian Constitution.

${ }^{95}$ Ibid [48]. 
